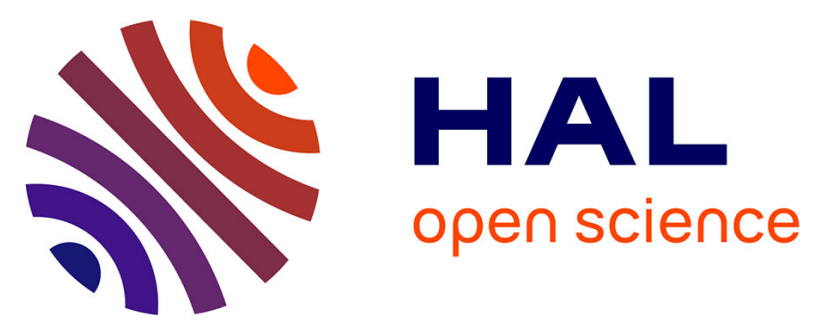

\title{
Plant trait-digestibility relationships across management and climate gradients in permanent grasslands
}

Antoine Gardarin, Éric Garnier, Pascal Carrère, Pablo Cruz, Donato

Andueza, Anne Bonis, Marie-Pascale Colace, Bertrand Dumont, Michel Duru, Anne Farruggia, et al.

\section{To cite this version:}

Antoine Gardarin, Éric Garnier, Pascal Carrère, Pablo Cruz, Donato Andueza, et al.. Plant traitdigestibility relationships across management and climate gradients in permanent grasslands. Journal of Applied Ecology, 2014, 51 (5), pp.1207-1217. 10.1111/1365-2664.12293 . hal-01093520

HAL Id: hal-01093520

https://hal-univ-rennes1.archives-ouvertes.fr/hal-01093520

Submitted on 28 May 2020

HAL is a multi-disciplinary open access archive for the deposit and dissemination of scientific research documents, whether they are published or not. The documents may come from teaching and research institutions in France or abroad, or from public or private research centers.
L'archive ouverte pluridisciplinaire HAL, est destinée au dépôt et à la diffusion de documents scientifiques de niveau recherche, publiés ou non, émanant des établissements d'enseignement et de recherche français ou étrangers, des laboratoires publics ou privés.

\section{()(1)(2)}

Distributed under a Creative Commons Attribution - ShareAlikel 4.0 International 


\title{
Plant trait-digestibility relationships across management and climate gradients in permanent grasslands
}

\author{
Antoine Gardarin ${ }^{1 *}$, Éric Garnier ${ }^{2}$, Pascal Carrère ${ }^{3}$, Pablo Cruz ${ }^{4,5}$, Donato Andueza ${ }^{6}$, Anne \\ Bonis $^{7}$, Marie-Pascale Colace ${ }^{8}$, Bertrand Dumont ${ }^{6}$, Michel Duru ${ }^{4,5}$, Anne Farruggia ${ }^{6}$, \\ Stéphanie Gaucherand ${ }^{9}$, Karl Grigulis ${ }^{10}$, Éric Kernéis ${ }^{11}$, Sandra Lavorel ${ }^{8}$, Frédérique Louault $^{3}$, \\ Grégory Loucougaray $^{9}$, François Mesléard ${ }^{12,13}$, Nicole Yavercovski ${ }^{12}$ and Elena Kazakou ${ }^{1}$ \\ ${ }^{1}$ Montpellier SupAgro, Centre d'Écologie Fonctionnelle et Évolutive (UMR5175), 1919 route de Mende, 34293 \\ Montpellier, France; ${ }^{2}$ CNRS, Centre d'Écologie Fonctionnelle et Évolutive (UMR5175), 1919 route de Mende, 34293 \\ Montpellier, France; ${ }^{3}$ INRA, UR874 Écosystème Prairial, 5 chemin de Beaulieu, 63039 Clermont-Ferrand, Cedex 2, \\ France; ${ }^{4}$ INRA, UMR1248 AGIR, Agroécologie, Innovation et Territoire, 31320 Castanet-Tolosan, France; ${ }^{5}$ Université \\ Toulouse, INPT, UMR, AGIR, 31029 Toulouse, France; ${ }^{6}$ INRA, UMR1213 Herbivores, 63122 Saint-Genès \\ Champanelle, France; ${ }^{7}$ CNRS, UMR6553 Écosystèmes Biodiversité Évolution, Campus de Beaulieu, 35042 Rennes,

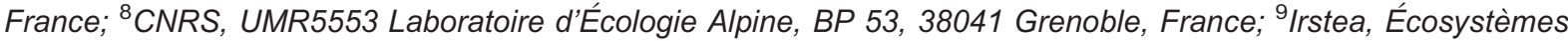 \\ Montagnards, 2 rue de la Papeterie, BP 76, 38402 Saint Martin d'Hères, France; ${ }^{10}$ CNRS, UMS3370 Station Alpine \\ Joseph Fourier, BP 53, 38041 Grenoble, France; ${ }^{11}$ INRA, UE0057 DSLP, Domaine du bois Maché, 17450 Saint- \\ Laurent-de-la-Prée, France; ${ }^{12}$ Centre de recherche de la Tour du Valat, Le Sambuc, 13200 Arles, France; and \\ ${ }^{13}$ Université d' Avignon et des Pays du Vaucluse, Institut Méditerranéen de Biodiversité et d'Écologie, BP1207, 84914 \\ Avignon, France
}

\section{Summary}

1. Dry matter digestibility is a critical component of herbage nutritive value, a major service delivered by grasslands. The aim of this study was to test whether the dominance hypothesis applies to assess the impacts of environmental gradients and management regimes on this component of herbage nutritive value in permanent grasslands.

2. At the plant level, digestibility has been related to a number of functional traits, but whether this can be scaled up to the community level in species-rich grasslands and how such relationships are modulated by environmental conditions and management regimes remain unknown. Our primary objective was to test whether community-weighted means - species trait values weighted by the species abundance - of morphological, phenological and chemical traits could be used to explain variations in digestibility over a large range of climatic contexts, soil resource levels and management regimes. Our second objective was to explain variations in community digestibility within and among nine contrasting sites along large natural and man-induced environmental gradients.

3. Over the whole data set, digestibility and most community-weighted means of traits responded to climatic factors and management regimes, but relations were not always significant when each site was considered separately. Community digestibility was significantly related to one or more plant traits within each site and to all of the measured traits when considering all the sites. Leaf dry matter content (LDMC) had the most consistent effects on digestibility, with a strikingly similar negative effect within each site. Potential evapotranspiration was negatively related to digestibility and contributed to explain a large part of the among-site variance. In addition, a low return interval of disturbance and a high disturbance intensity (biomass removal) were both associated with a high digestibility.

4. Synthesis and applications. Disturbance regime, plant traits and local climate impacted dry matter digestibility roughly equally in grasslands. The effects of community composition on

\footnotetext{
*Correspondence author. E-mail: Antoine.Gardarin@grignon.inra.fr
} 
digestibility and its response to abiotic factors could be successfully captured by communityweighted means of leaf dry matter content. This functional marker can be used to develop indicators and grassland management rules to support farmers in the refinement of their practices towards specific needs, such as target production outputs.

Key-words: community digestibility, disturbance intensity, dominance hypothesis, drought, ecosystem property, functional traits, leaf dry matter content, nitrogen nutrition index, nutritional value, potential evapotranspiration

\section{Introduction}

Permanent grasslands provide a wide range of goods and services whose delivery strongly relies on plant diversity (Lemaire, Hodgson \& Chabbi 2011). At the field scale, grassland management for production usually conflicts with grassland management for conservation or other purposes (Klimek et al. 2007). Modifications of fertilization and mowing practices towards more extensive management regimes lead to a reduction in the overall forage quality (Lavorel et al. 2011) and to contrasting effects on plant diversity (Marriott et al. 2004). To assess efficiently ecosystem services in grasslands, there is an urgent need to improve our understanding of (i) the mechanisms that link community structural and functional composition to their functions, and these functions to the delivered services and (ii) the responses of grassland communities to environmental factors (i.e. water availability) and land use (i.e. intensity of exploitation) in order to propose management practices that will improve the delivery of services.

Together with the amount and the timing of production, dry matter digestibility is a critical component of herbage nutritive value and provides a synthetic measure of the amount of energy available for herbivores in plant constituents (Bruinenberg et al. 2002). A large variability in digestibility can be observed across grasslands, resulting from variations in botanical composition, climate and management regimes, because of their distinct effects on herbage structure (proportion of structural tissues) and on tissue ageing which reduce digestibility (Duru 2008).

Digestibility varies with climate variables (Craine et al. 2010) via the negative effects of high temperatures accelerating tissue ageing at the seasonal scale (Hirata 1999), or via the selection of drought-resistant species in arid regions (Guérin 1999). At the plant level, fertilization practices tend to favour species with low tissue density which are thus highly digestible (Rodrigues et al. 2007), but also enhance herbage growth and fast tissue ageing together with accelerated phenology, generally resulting in a rapid decrease in digestibility (Duru et al. 2000; Duru \& Ducrocq 2002). Disturbances affect community composition by selecting species with fast regrowth ability, in relation with a low tissue density (Díaz, Noy-Meir \& Cabido 2001), leading to a more digestible forage in more disturbed areas compared with less disturbed ones, when assessed at similar phenological stages (Pavlů et al. 2006; Henkin et al. 2011). In addition to the indirect long-term effects, frequent herbage removal maintains swards at high digestibility levels (Garcia et al. 2003).

Digestibility results from the variations in structural: metabolic tissue ratio, depending on plant development, and from the temporal variation in the digestibility of structural tissues as they age (Duru et al. 2008). The poorly digestible biomass fraction in plant tissues relates to high structural carbohydrates content in cell walls together with a high degree of lignification (Choong et al. 1992; Bruinenberg et al. 2002). These properties can be assessed through the use of functional traits (sensu Violle et al. 2007), as shown by a number of studies conducted at the species level: specific leaf area (SLA: the ratio of leaf area to dry mass) and leaf nitrogen concentration (LNC) generally correlate positively with digestibility (Duru, Cruz \& Magda 2004; Al Haj Khaled et al. 2006; Pontes et al. 2007a), while leaf dry matter content (LDMC: the ratio of leaf dry mass to water-saturated fresh mass) and leaf life span tend to correlate negatively (Louault et al. 2005; Al Haj Khaled et al. 2006; Pontes et al. 2007a). How these relationships scale to the ecosystem level in species-rich grasslands remains an open question, since in spite of their recognized ecological value, little is known about the nutritive value of these systems (e.g. Duru et al. 2008). The dominance hypothesis (Grime 1998), which states that the 'the extent to which the traits of a species affect ecosystem properties is likely to be strongly related to the contributions of the species [...]' to the biomass of the community, provides a framework to understand this scaling up from species to ecosystem properties (see Garnier \& Navas 2012; Lavorel \& Grigulis 2012 for reviews).

The dominance hypothesis as applied to digestibility has been tested in few situations, and in somewhat different ways. Using a discrete approach based on the classification of grass species in different types, Duru et al. (2008) and Ansquer et al. (2009) showed that grasslands with a high proportion of grasses with low leaf dry matter content had a higher digestibility than grasslands dominated by grasses with a high leaf dry matter content. A more formal test of the dominance hypothesis requires the analyses of relationships between community-weighted means of traits (CWM: the product of the mean trait value 
of a species by its relative abundance in the community, Garnier et al. 2004) and the property under consideration. Ansquer et al. (2009) found a negative relationship between digestibility and the proportion of a plant functional type consisting in stress-tolerant species with high leaf dry matter content, calculated for grasses in 18 grassland plots, while Andueza et al. (2010) found a negative relationship between CWM of leaf dry matter content and digestibility in a comparison of two meadows differing in management intensity. Finally, Lavorel and Grigulis (2012) found a positive relationship between digestibility and CWM of leaf nitrogen concentration in a set of 63 montane grassland plots.

We therefore still have only limited evidence as to whether the dominance hypothesis applies to the digestibility of species-rich grasslands and which trait is likely to better capture this important ecosystem property. To our knowledge, there is currently no analysis reporting how far plant functional traits can capture variations in grassland digestibility in response to both environmental conditions (e.g. climatic; Rodrigues et al. 2007; Craine et al. 2010) and management. Our primary objective was therefore to test whether community-weighted means of traits could be used to explain variations in digestibility over a large range of climatic contexts, soil resource levels and management regimes.

We first hypothesize that environment and grassland management regimes modify herbage digestibility and community-weighted means of plant and leaf traits. For instance, we expect communities growing under highly disturbed regimes (e.g. intensive grazing) to have high SLA and low LDMC values associated with a high digestibility, and communities growing in stressed conditions (e.g. water stress, no fertilization) to have high LDMC and low digestibility. Secondly, we predict that several communityweighted means of traits, which could integrate vegetation response to environmental factors (including those induced by management), relate to herbage digestibility at the community level, in agreement with the dominance hypothesis. Finally, we hypothesize that the shape of relationships between community-weighted means of traits and digestibility would vary between different geographical locations, depending on climate or management factors.

To test these hypotheses, we measured variations in community digestibility in nine permanent grasslands across France, spanning a wide range of climate and management conditions.

\section{Material and methods}

\section{STUDY SITES AND EXPERIMENTAL DESIGN}

The study was conducted in permanent grasslands located across nine French pedoclimatic regions, covering a wide gradient of climate conditions (Table 1), ranging from subalpine to Mediterranean. Within each site, 2-6 management regimes were identified based on the intensity of grazing or mowing, grazing species (cattle, sheep or horses) and soil fertility (see Table S1, Supporting Information). Management regimes consisted in 2-4 disturbance levels in five sites, in three levels of soil fertility in another site and in the combinations of these factors (from 3 to 6 management regimes) in the three remaining sites.

Within each site, each management regime was applied in a number of plots, and the distance between plots ranged from at least $10 \mathrm{~m}$ up to a few $\mathrm{km}$. Plots were placed in different plant

Table 1. Geographical and climate conditions of the nine sites selected for this study (adapted from Dumont et al. 2012)

\begin{tabular}{|c|c|c|c|c|c|c|c|c|c|}
\hline Site & Code & Coordinates & $\begin{array}{l}\text { Altitude } \\
\text { range } \\
\text { (m a.s.l.) }\end{array}$ & Climate & $\begin{array}{l}\text { Mean annual } \\
\text { temperature } \\
\left({ }^{\circ} \mathrm{C}\right)\end{array}$ & $\begin{array}{l}\text { Annual } \\
\text { rainfall } \\
(\mathrm{mm})\end{array}$ & $\begin{array}{l}\text { Potential } \\
\text { evapo- } \\
\text { transpiration } \\
\text { during plant } \\
\text { growth (mm) }\end{array}$ & $\begin{array}{l}\text { Number of } \\
\text { management } \\
\text { regimes }\end{array}$ & $\begin{array}{l}\text { Number } \\
\text { of plots }\end{array}$ \\
\hline Ercé & $\mathrm{ERC}$ & $\begin{array}{c}42^{\circ} 5^{\prime} \mathrm{N} \\
1^{\circ} 2^{\prime} \mathrm{E}\end{array}$ & $600-1000$ & $\begin{array}{l}\text { Montane } \\
\text { suboceanic }\end{array}$ & $10 \cdot 0$ & 1079 & 469 & 6 & 16 \\
\hline La Fage & FAG & $\begin{array}{c}43^{\circ} 6^{\prime} \mathrm{N} \\
3^{\circ} 0^{\prime} \mathrm{E}\end{array}$ & $765-830$ & $\begin{array}{l}\text { Mediterranean } \\
\text { subhumid }\end{array}$ & $9 \cdot 5$ & 1074 & 484 & 3 & 12 \\
\hline Col du Lautaret & LAU & $\begin{array}{c}45^{\circ} 0^{\prime} \mathrm{N} \\
6^{\circ} 2^{\prime} \mathrm{E}\end{array}$ & $1900-2100$ & Subalpine & $3 \cdot 0$ & 902 & 311 & 6 & 24 \\
\hline Les Magnils & MAG & $\begin{array}{r}46^{\circ} 3^{\prime} \mathrm{N} \\
1^{\circ} 1^{\prime} \mathrm{W}\end{array}$ & 8 & Oceanic & $12 \cdot 7$ & 838 & 511 & 3 & 18 \\
\hline Marcenat & MAR & $\begin{array}{c}45^{\circ} 2^{\prime} \mathrm{N} \\
2^{\circ} 5^{\prime} \mathrm{E}\end{array}$ & $1080-1130$ & Continental & $7 \cdot 3$ & 1142 & 431 & 3 & 6 \\
\hline Les Saisies & SAI & $\begin{array}{c}45^{\circ} 5^{\prime} \mathrm{N} \\
6^{\circ} 3^{\prime} \mathrm{E}\end{array}$ & $1670-1990$ & Subalpine & $5 \cdot 0$ & 1569 & 211 & 3 & 6 \\
\hline $\begin{array}{l}\text { Saint-Laurent } \\
\text { de-la-Prée }\end{array}$ & SLP & $\begin{array}{r}45^{\circ} 6^{\prime} \mathrm{N} \\
1^{\circ} 0^{\prime} \mathrm{W}\end{array}$ & $2-3$ & Oceanic & $12 \cdot 6$ & 772 & 530 & 2 & 4 \\
\hline Tour du Valat & TDV & $\begin{array}{c}43^{\circ} 5^{\prime} \mathrm{N} \\
4^{\circ} 7^{\prime} \mathrm{E}\end{array}$ & $0 \cdot 5-1$ & Mediterranean & $14 \cdot 9$ & 583 & 355 & 3 & 18 \\
\hline Theix & THE & $\begin{array}{c}45^{\circ} 7^{\prime} \mathrm{N} \\
3^{\circ} 0^{\prime} \mathrm{E}\end{array}$ & $870-885$ & Continental & $8 \cdot 7$ & 770 & 433 & 4 & 16 \\
\hline
\end{tabular}


communities identified on the basis of vegetation composition surveys stratified by land use, topography, altitude, geological substrate and soil type (average across sites: 3.6 plots per management regime), providing a total of 120 plots for the nine sites (Table 1).

\section{ENVIRONMENTAL VARIABLES AND MANAGEMENT REGIMES}

Historical records of temperatures $\left({ }^{\circ} \mathrm{C}\right)$, rainfall $(\mathrm{mm})$ and global radiation $\left(\mathrm{W} \mathrm{h}^{-1} \mathrm{~m}^{-2}\right.$ ) were obtained from meteorological stations located at each study site for the past 30 years. These historical records were very close to weather conditions prevailing during the actual year of field measurements (correlation coefficients between similar variables exceeding $0.90(P<0.0001$, cf also Dumont et al. 2012). Potential evapotranspiration during plant growth (PET) was computed using Hargreaves formula (Hargreaves \& Allen 2003). Two drought descriptors were then calculated over the period of vegetation growth (Fig. 1a, b): (i) the duration of the drought period and (ii) the drought intensity, estimated when the useful water reserve fell below $70 \%$ of field capacity (Appendix S1, Supporting Information).

Two indicators were used to characterize the disturbance regimes in each plot: (i) the disturbance intensity $\left(\mathrm{g} \mathrm{g}^{-1}\right)$ corresponding to the proportion of biomass removed annually by grazing or by mowing, relative to the total biomass produced, and (ii) the mean return interval between two disturbances (in years), this index being lower than 1 for plots disturbed several times per year and above 1 for abandoned plots. A high level of disturbance thus corresponds to a high proportion of biomass removed with a short return interval. The disturbance intensity was null in abandoned plots, lower than $0.10 \mathrm{~g} \mathrm{~g}^{-1}$ in extensive grasslands and could exceed $0.50 \mathrm{~g} \mathrm{~g}^{-1}$ in intensively grazed or mown pastures (Fig. 1c). The mean return interval of disturbance was the lowest (from 0.03 to 0.2 years) in continuously grazed pastures and comprised between 3 and 20 years in abandoned grasslands (Fig. 1d).

Nutrient limitation was assessed using nutrition indices at the plot level, on the same herbage samples as those used to assess digestibility (see section 2.3) or on additional samples collected nearby. The (a)

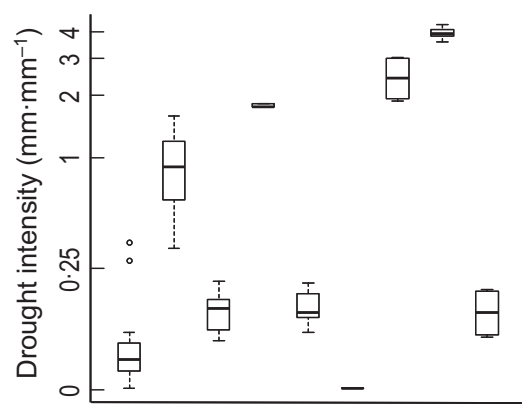

(c)

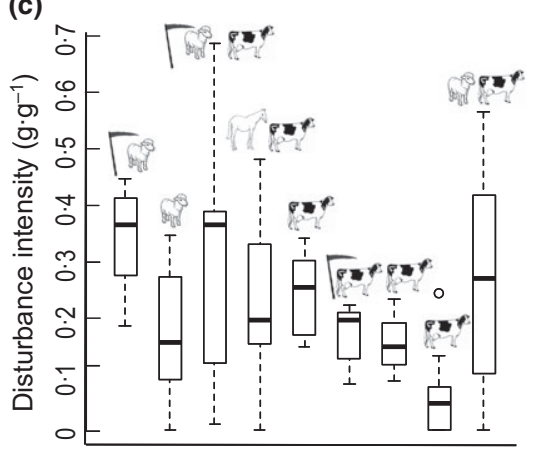

(e)

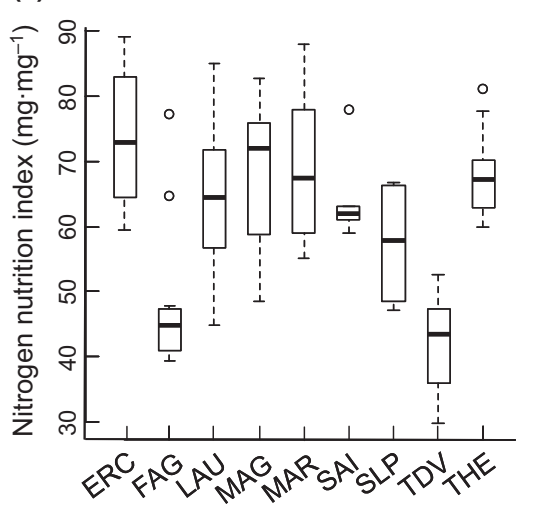

(b)

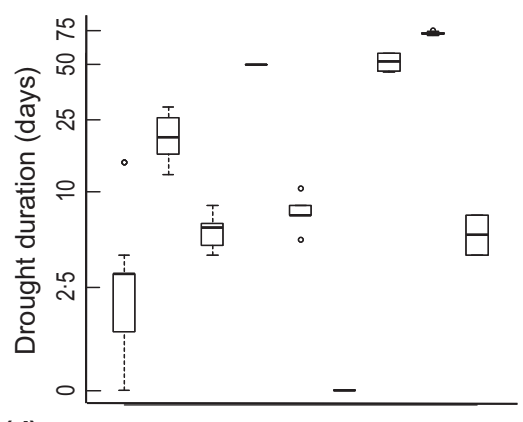

(d)

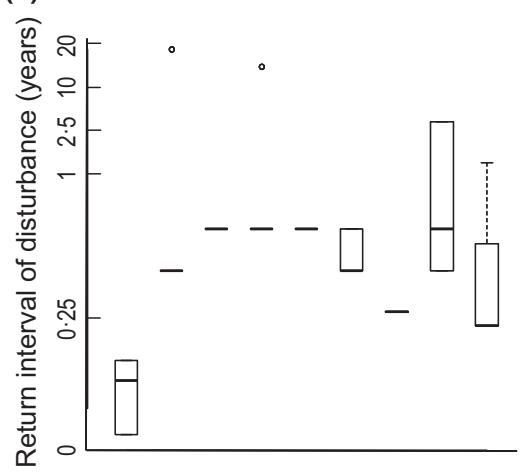

(f)

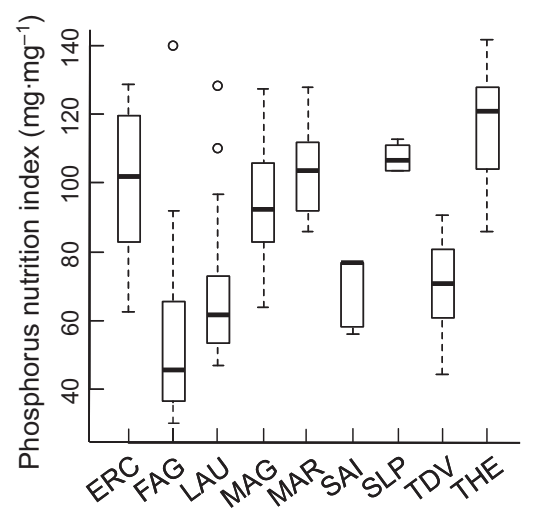

Fig. 1. Range of variation in management regimes and of drought conditions at the plot level in the nine sites selected for this study. Symbols in panel C indicate mowing or sheep, horse or cattle grazing. Box: first, second and third quartiles; whiskers: $1.5 \times$ interquartile range. ERC, LAU and SAI, upland sites with montane and subalpine climate; MAR and THE, continental climate; MAG and SLP, oceanic climate; FAG and TDV, Mediterranean climate. For further details on climate and management regimes in each site, see Table 1 . 
nitrogen nutrition index (NNI) was determined as the ratio between the actual nitrogen concentration of the above-ground biomass and the critical concentration indicating the minimum $\mathrm{N}$ content required for the maximum biomass production (Appendix S1, Supporting Information). NNI varied from approximately $30 \%$ in nitrogenlimited management regimes up to $80-90 \%$ in management regimes with low nitrogen limitation (Fig. 1e). The phosphorus nutrition index (PNI) was determined as the ratio between the actual Olsen phosphorus concentration of the above-ground biomass and the critical concentration (Appendix S1, Supporting Information). PNI was generally below $60 \%$ in extensively managed plots and exceeded $100 \%$ in intensively managed ones (Fig. 1f).

All management variables strongly varied within sites, thus reducing pseudo-replication risks among sites (Fig. 1c-f). Climate-related variables were strongly site dependent. However, possible confounding effects with other, unstudied, site-specific conditions were minimized by the fact that 4 of the 5 types of climatic situations in our data set were each represented by two geographical sites.

\section{COMMUNITY DIGESTIBILITY}

In each plot, an average of 2.3 replicates (ranging from 1 to 4 ) of above-ground biomass samples were collected close to the vegetative peak under exclusion cages, resulting in 276 samples. Samples were dried at $60{ }^{\circ} \mathrm{C}$ for $48 \mathrm{~h}$, and their dry mass $\left(\mathrm{g} \mathrm{m}^{-2}\right)$ was weighed. Maximum green biomass was also measured on adjacent subplots (with the same community) by cutting a herbage sample around the time of peak biomass. The ratio between the green standing biomass sampled for digestibility and the maximum green biomass (both expressed on a dry mass basis) was used as an indicator of herbage phenological stage (the closer to 1 this ratio, the later the phenological stage).

To estimate community digestibility, each dry sample was ground using a mill (Cyclotec; model 1093 FOSS-TECATOR Inc., Höganäs, Sweden) to pass through a 1-mm screen. Samples were submitted to near-infrared reflectance spectroscopy to determine dry matter digestibility $\left(\mathrm{g} \mathrm{kg}^{-1}\right)$. Spectra were collected with a monochromator (FOSS-NIR Systems 6500, Silver Spring, MD, USA) which scans the spectral range of $400-2500 \mathrm{~nm}$. The calibration was based on 97 samples selected from their spectral information (Shenk \& Westerhaus 1994), which were analysed for pepsin-cellulase dry matter digestibility according to the method proposed by Aufrère and Michaet-Doreau (1983). The $R^{2}$ of cross-validation of the calibration model was 0.97.

\section{FUNCTIONAL COMPOSITION OF THE VEGETATION}

Botanical composition was assessed in each plot to determine species abundance (related to their above-ground biomass, Barkaoui, Bernard-Verdier \& Navas 2013) between the vegetative peak and the peak-standing biomass, using the point-intercept method in quadrat or transects depending on the site. The botanical composition of each site was clearly different. Over the 41 species that composed the 'main species list' (species with a mean relative abundance higher than $10 \%$ in at least one site), only $7-33 \%$ of them were found in each site (Table S2, Supporting Information). This was also true within climatic zones, with a degree of species overlap comprised between 17 and 29\% (Table S2, Supporting Information).

For each site and management regime, seven leaf or plant traits were measured following standardized protocols (Cornelissen et al. 2003) for the dominant species, that is, those species that collectively made up at least $80 \%$ of the total biomass in the plot community. We measured (i) a whole plant trait: the reproductive plant height (RPH, distance between the ground level and the upper boundary of the reproductive organs, $\mathrm{cm}$ ), (ii) morphological leaf traits: leaf dry matter content (LDMC, the oven-dry mass of a leaf divided by its water-saturated fresh mass, $\mathrm{mg} \mathrm{g}^{-1}$ ), specific leaf area (SLA, the ratio of one-sided area of a fresh leaf by its oven-dry mass, $\mathrm{m}^{2} \mathrm{~kg}^{-1}$ ), (iii) chemical leaf traits: leaf nitrogen concentration ( $\mathrm{LNC}, \mathrm{mg} \mathrm{g}^{-1}$ ) and leaf phosphorus concentration (LPC, $\mathrm{mg} \mathrm{g}^{-1}$ ) and (iv) a phenological trait: the onset of flowering expressed in degree-days (OFL, sum of positive daily temperatures, ceiling temperature $=18{ }^{\circ} \mathrm{C}$, from the first day of the year with positive temperatures until flowering onset, ${ }^{\circ} \mathrm{C} \mathrm{d}$ ). Morphological traits were determined on 10-30 individuals per species depending on traits (see Cornelissen et al. 2003) and chemical traits on 1-3 replicates, resulting from the pooling of the leaves used for morphological trait measurement. Finally, the percentage of therophyte species (annuals) was also taken into account, as a parameter describing community structure.

Community-weighted means of traits were computed for each plot as the mean of trait values trait ${ }_{i}$ weighted by the relative abundance $p_{i}$ of each species $i$ (Garnier et al. 2004):

$\mathrm{CWM}_{\text {trait }}=\sum_{i} p_{i} \times$ trait $_{i}$

\section{STATISTICAL ANALYSES}

Statistical analyses were performed under the $\mathrm{R}$ environment (R Development Core Team, 2008). Data collected within each plot for the different replicates were averaged. Single and multiple linear regressions between the different groups of variables were used. To account for differences in the variance of digestibility among plots (Fig. S1, Supporting Information), sums of squares were weighted by the inverse of variance in digestibility when it was the explained variable (option weight of functions $l m$ and lmer, package stats). As a result, digestibility measurements associated with a low variance (and thus with a high confidence) were given a higher importance in regression models than those with a high variance. Data were standardized to allow comparisons of the effects of the different variables. All the variables (but site) were continuous. The variables describing drought intensity and return interval of disturbance were $\log _{10}$-transformed to correct their right-skewed distributions. In individual site analyses, regressions were performed with fixed effects (function $l m$, package stats). To account for potential pseudo-replication at site level when all sites were incorporated in the analysis, linear mixed models with a constant random site effect were used (function lmer, package lme4). Interactions between random site effects and independent variables were also introduced in the mixed models, but they were not significant.

The equations of the tested regressions are detailed in Appendix S1 (Supporting Information). First, we carried out linear regressions to assess the effects of drought (intensity and duration) and management regimes (intensity and return interval of disturbance, NNI and PNI) on community digestibility at each site and among sites. Secondly, we used linear regressions to analyse the effects of climate variables and management regimes (the same as above plus mean annual rainfall, temperature, PET and altitude) on community-weighted means of traits and community structure between sites. Thirdly, we studied the effects of community-weighted means of traits (LDMC, SLA, LNC, LPC, RPH, OFL) and community composition in biological types (percentage 
of therophytes) on digestibility, within and among sites, using linear regressions. To account for possible differences in phenological stages when digestibility was measured, we also included the indicator of phenological stage as a possible explanatory variable. In these analyses, $P$-values were used to assess the significance of each explanatory variable.

Finally, using manual backward and forward stepwise multiple regressions, we searched for a linear mixed model (with random site effects on the intercept and slopes) combining the effects of climate, management regimes, community-weighted means of traits, proportion of therophytes and the indicator of phenological progress (explanatory variables) to predict digestibility (explained variable). The best model was selected using the corrected Akaike Information Criterion (package AICcmodavg, function AICc.mer), which is recommended for small data sets (Burnham \& Anderson 2002). Data were standardized in order to consider possible interactions between explanatory variables. All possible first-order interactions between the remaining significant factors were then introduced in the models using backward and forward selection procedures along with the Akaike Information Criteria. To provide a measure of the relative importance of each variable $v$ in the final regression, we calculated the ratio of the sum of Akaike weights of the models including the variable $v$ over the sum of Akaike weights of the models that do not, as proposed in Burnham and Anderson (2002, p.167).

We checked and confirmed the homoscedasticity and normality of the residuals, respectively, by plotting residuals vs. predicted values and using normal probability plots. The linearity of the effects was verified by checking that there was no general pattern in the plots of residuals vs. independent variables.

\section{Results}

\section{CLIMATE AND MANAGEMENT EFFECTS ON COMMUNITY DIGESTIBILITY}

Among-site analyses showed that annual rainfall, mean annual temperature, mean altitude and potential evapotranspiration did not directly affect digestibility (results not shown). When all sites were considered, community digestibility was negatively related to soil drought intensity and duration (Table 2). A similar and stronger effect was found in the two Mediterranean sites (FAG and TDV). Digestibility correlated positively with the intensity of disturbance in four sites, with a relatively similar slope in three of them (Table 2). Thus, over the whole data set, increasing the proportion of removed biomass by $0.10 \mathrm{~g} \mathrm{~g}^{-1}$ led to a mean increase in digestibility of $29.1 \mathrm{~g} \mathrm{~kg}^{-1}$ (Fig. 2). Similarly, digestibility decreased with an increasing return interval of disturbance. Effects of nutrients availability were less clear. Phosphorus availability was positively related to digestibility within a few sites and over the whole data set. Conversely, nitrogen nutrition index had an overall negative effect, but slopes differed when considering each site independently.

\section{CLIMATE AND MANAGEMENT EFFECTS ON COMMUNITY-WEIGHTED MEANS OF TRAITS}

Climate factors significantly affected only few communityweighted means of traits (see Table S3, Supporting Information). LDMC was the highest in sites with low evapotranspiration, while SLA and OFL decreased with increasing altitude. The proportion of therophytes was the highest at low altitude sites, with high temperatures and marked drought periods.

By contrast, management regimes influenced strongly the community-weighted means of traits (see Table S3, Supporting Information). High levels of disturbance (high proportion of biomass removed, small return interval) and high levels of nutrient availability (nitrogen and especially phosphorus nutrition indices) were generally associated with communities showing low LDMC, high SLA, LNC, LPC and RPH values.

Table 2. Effects of climate variables and management regime on community digestibility in permanent grasslands in nine sites in France. Results of linear regressions on standardized data. Values are slopes of linear regressions followed by levels of significance

\begin{tabular}{|c|c|c|c|c|c|c|}
\hline \multirow[b]{2}{*}{ Sites } & \multicolumn{2}{|c|}{ Climate descriptors } & \multicolumn{4}{|c|}{ Management regime } \\
\hline & $\begin{array}{l}\text { Drought } \\
\text { intensity }\end{array}$ & $\begin{array}{l}\text { Drought } \\
\text { duration }\end{array}$ & $\begin{array}{l}\text { Disturbance } \\
\text { intensity }\end{array}$ & $\begin{array}{l}\text { Return interval } \\
\text { of disturbance }\end{array}$ & $\begin{array}{l}\text { Nitrogen } \\
\text { nutrition index }\end{array}$ & $\begin{array}{l}\text { Phosphorus } \\
\text { nutrition index }\end{array}$ \\
\hline ERC & ns & ns & ns & ns & ns & ns \\
\hline FAG & $-1.76^{* * *}$ & $-2 \cdot 86^{* *}$ & $1 \cdot 01^{* *}$ & $-0.74^{\dagger}$ & $0 \cdot 85^{* *}$ & $0.48 * * *$ \\
\hline LAU & ns & ns & $0 \cdot 61^{* *}$ & - & ns & ns \\
\hline MAG & ns & - & $0 \cdot 51^{* *}$ & $-0 \cdot 81^{* *}$ & $-0 \cdot 82 * * *$ & ns \\
\hline MAR & ns & ns & ns & - & ns & ns \\
\hline SAI & - & - & ns & ns & $0.67 *$ & ns \\
\hline SLP & ns & ns & ns & - & ns & ns \\
\hline TDV & $-9 \cdot 15^{*}$ & $-14.92^{*}$ & ns & $-0 \cdot 56^{*}$ & ns & ns \\
\hline THE & ns & ns & $0.51 * *$ & $-0.79 * * *$ & ns & $0.96^{*}$ \\
\hline All sites & $-0.34^{*}$ & -0.29 & $0 \cdot 50 * * *$ & $-0.75^{* * *}$ & $-0 \cdot 31 * *$ & $0 \cdot 28 * * *$ \\
\hline
\end{tabular}

"- means that the model could not be evaluated because of a lack of variability of this factor in this site.

ERC, LAU and SAI, upland sites with montane and subalpine climate; MAR and THE: continental climate; MAG and SLP, oceanic climate; FAG and TDV, Mediterranean climate. For further details on climate and management regimes in each site, see Table 1 and Fig. 1.

Notes: ns, not significant; ${ }^{\dagger} 0.05<P<0.1 ; * P<0.05 ; * * P<0.01 ; * * * P<0.001$. 

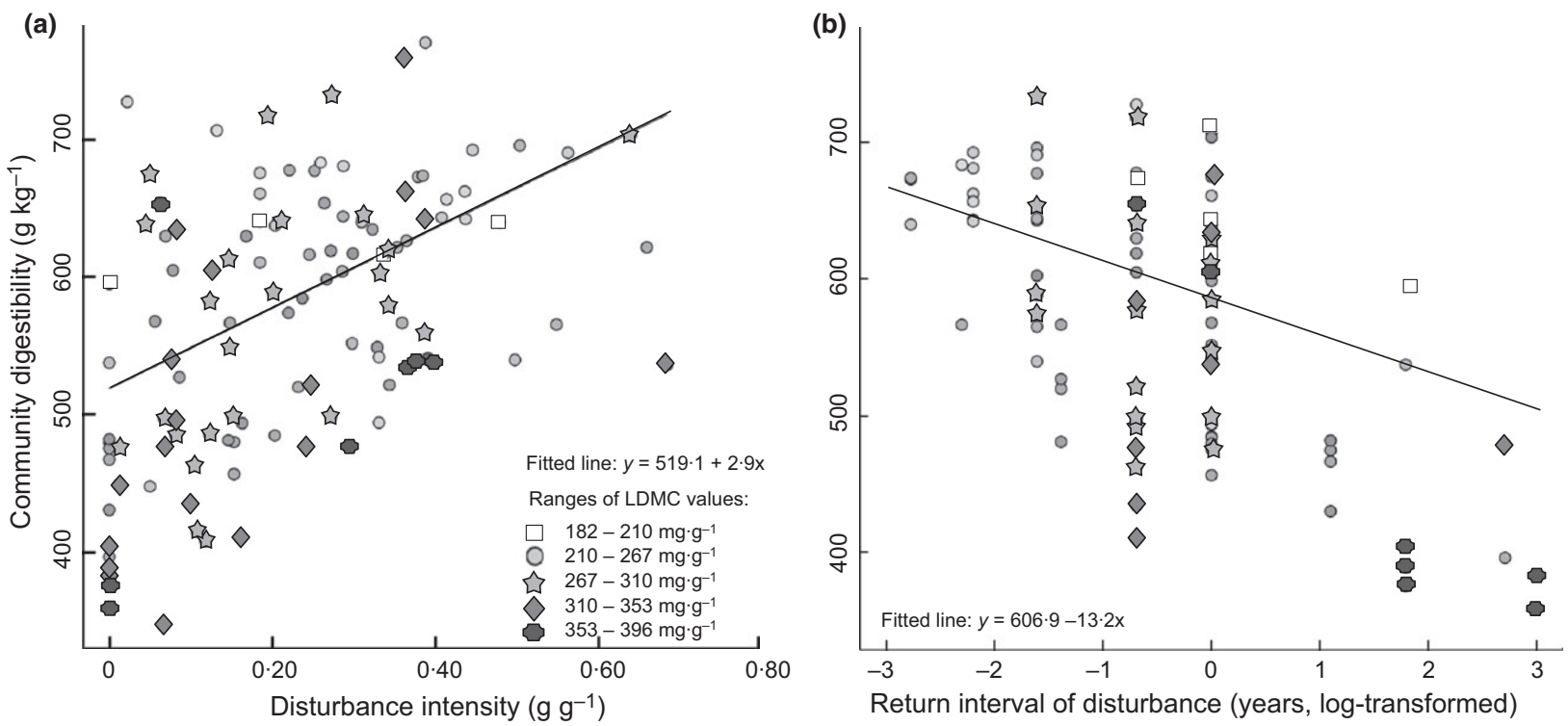

Fig. 2. Effect of disturbance intensity (a, percentage of biomass removed annually by grazing or mowing) and of the return interval of disturbance (b) on community digestibility at the plot level over the nine sites. Intensity of grey indicates variations in communityweighted mean of leaf dry matter content in each community varying from minimal (white) to maximal values (black). Regression lines are the results of linear mixed models (see Table 2).

\section{EFFECTS OF TRAITS AND COMMUNITY STRUCTURE ON DIGESTIBILITY}

Leaf dry matter content was negatively related to digestibility within six sites (Table 3 ) with a strikingly similar effect within each site: the slopes of the relationships were very close and did not significantly differ among sites (no significant site $\times$ LDMC interaction in the mixed model analysis, Fig. 3). Over the whole data set, a similar negative relationship was observed between LDMC and digestibility.

Digestibility was also positively related to SLA, LNC, LPC and to the proportion of therophytes, and negatively to RPH within and among sites (Table 3), but the explanatory power of these variables was lower than that of LDMC. Across sites, the onset of flowering date had a positive effect on digestibility, but the sign of this effect varied when considering each site independently: late flowering communities tended to be more digestible at two sites (LAU with subalpine climate and TDV with a Mediterranean climate) but less digestible in FAG (Mediterranean climate).

At a majority of sites and over the whole data set, digestibility decreased when the indicator of phenological stage increased (Table 3).

\section{COMBINED EFFECTS OF CLIMATE, MANAGEMENT FACTORS AND TRAITS TO PREDICT COMMUNITY DIGESTIBILITY}

Leaf dry matter content, potential evapotranspiration and disturbance intensity were the three most important variables, with comparable importance in the multiple regression model comprising random site effects $\left(R^{2}=0.63\right.$,

Table 3. Effects of community-weighted means of traits and community structure on digestibility in permanent grasslands over nine sites in France. Results of linear regressions on standardized data (mixed model with a random site effect for the last line). Values are slopes of linear regressions followed by levels of significance

\begin{tabular}{|c|c|c|c|c|c|c|c|c|}
\hline \multirow[b]{2}{*}{ Sites } & \multicolumn{6}{|c|}{ Community-weighted means of traits } & \multicolumn{2}{|c|}{ Community characteristics } \\
\hline & LDMC & SLA & LNC & LPC & $\mathrm{RPH}$ & OFL & $\begin{array}{l}\text { Proportion of } \\
\text { therophytes }\end{array}$ & $\begin{array}{l}\text { Indicator of } \\
\text { phenological stage }\end{array}$ \\
\hline ERC & $-0 \cdot 65^{\dagger}$ & ns & ns & ns & ns & ns & ns & - \\
\hline FAG & $-0 \cdot 89 * * *$ & $1 \cdot 35^{* * *}$ & ns & $0.71 * * *$ & ns & $-3 \cdot 59 * * *$ & $0.50 \dagger$ & $-0 \cdot 30 * *$ \\
\hline LAU & $-0.53^{*}$ & ns & $0.73^{*}$ & $1 \cdot 30^{* *}$ & ns & $1.58 \dagger$ & ns & ns \\
\hline MAG & $-0.68 *$ & $0.35 \dagger$ & ns & ns & $-0.87 * * *$ & ns & $0 \cdot 36^{*}$ & $-1.90 * *$ \\
\hline MAR & ns & ns & ns & ns & ns & ns & - & ns \\
\hline SAI & $-0.58 *$ & ns & ns & ns & ns & ns & $10 \cdot 25^{* *}$ & $-0.54 \dagger$ \\
\hline SLP & ns & ns & $1 \cdot 56^{*}$ & ns & ns & - & $1.75 \dagger$ & ns \\
\hline TDV & $-0.61 * * *$ & ns & $0.85^{* *}$ & $1.62 * * *$ & $-1.93 * * *$ & $0 \cdot 93^{* *}$ & $0.97 * *$ & $-0.27^{*}$ \\
\hline THE & ns & $2 \cdot 11 * *$ & ns & $1.69^{* *}$ & ns & - & - & ns \\
\hline All sites & $-0.64 * * *$ & $0.29 * * *$ & $0.20^{* * *}$ & $0.70^{* * *}$ & $-0.47 * * *$ & $0.27 * * *$ & $0.38 * * *$ & $-0.43^{* * *}$ \\
\hline
\end{tabular}

Abbreviations: see notes of Table 2. 


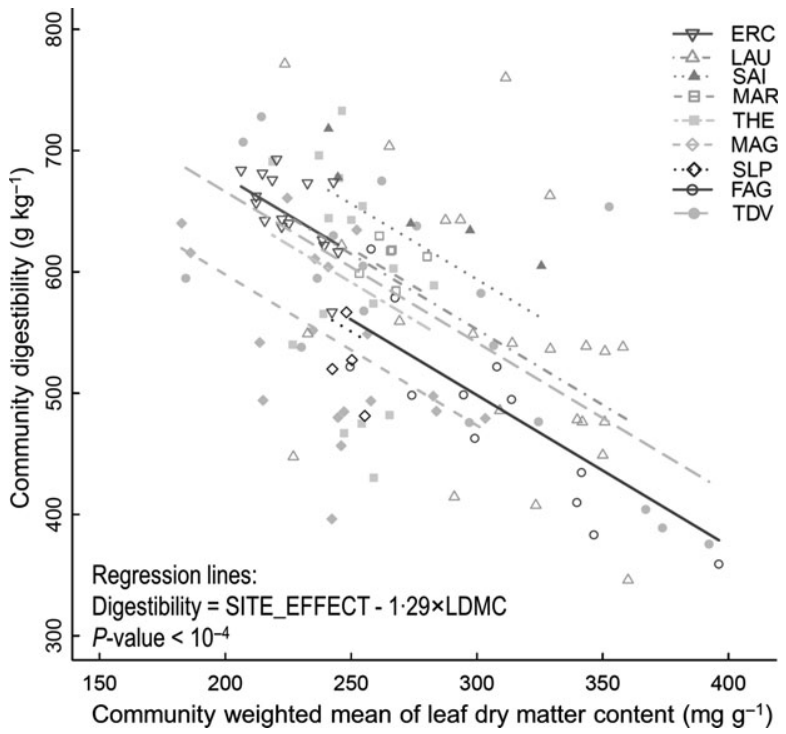

Fig. 3. Relationship between community-weighted means of leaf dry matter content (LDMC) and digestibility in permanent grasslands across nine sites. Regression lines are the result of a linear mixed model between digestibility and community-weighted means of leaf dry matter content, in all sites considered together, with a constant random site effect (the LDMC $\times$ site interaction was not significant, with the same slope for each site). The differences between the intercepts of each regression correspond to the random site effects and are represented in Fig. 4. ERC, LAU and SAI, upland sites with montane and subalpine climate (triangles); MAR and THE, continental climate (squares); MAG and SLP, oceanic climate (diamonds); FAG and TDV, Mediterranean climate (circles). For further details on climate and management regimes in each site, see Table 1 and Fig. 1.

Table 4). LDMC was the only trait selected in the regression, with a negative effect on digestibility. Other leaf traits, for instance SLA or LNC, were not included in the model as they did not explain any additional variance. LDMC was indeed negatively correlated with SLA (correlation coefficient $=-0.66, P<0.0001$ ) and LNC (correlation coefficient $=-0.50, P<0.0001$, results of additional statistical analyses).

Potential evapotranspiration (PET) was negatively related to digestibility and also contributed to explain a large part of the among-site variance in digestibility. Indeed, the y intercepts of within-site regressions between digestibility and LDMC (see section 3·1, Fig. 3) were negatively related to PET (Fig. 4), even if some sites (MAR, LAU and ERC) tended to have comparable intercepts. Therefore, for a given LDMC, digestibility was about $200 \mathrm{mg} \mathrm{g}^{-1}$ higher in sites with the lowest PET (e.g. SAI with subalpine climate) as compared to sites experiencing high PET (e.g. MAG with and SLP, both with oceanic climate). Other climate variables did not explain any additional variance. By contrast, management regime contributed to explain digestibility in the multiple regression, via the positive effect of disturbance intensity.

The proportion of therophytes in the community positively affected digestibility. This proportion varied between 0 and $15 \%$ in most sites, but was more variable (up to
Table 4. Effects of community-weighted means of traits, proportion of therophytes, climate variables and management regimes on community digestibility in permanent grasslands over nine sites in France. Results of a multiple linear regression model with a random site effect. For comparison with Tables 1 and 2, standardized effects are in parentheses

\begin{tabular}{lll}
\hline & Effect & $\begin{array}{l}\text { Relative importance } \\
\text { of the variable } \\
\text { (Akaike weights) }\end{array}$ \\
\hline $\begin{array}{ll}\text { Fixed effects } \\
\text { Intercept }\end{array}$ & $570 \cdot 30(0 \cdot 12)$ & \\
LDMC & $-0.85(-0 \cdot 42)$ & 0.99 \\
Potential & $-0.49(-0 \cdot 41)$ & 0.98 \\
$\quad$ evapotranspiration & & \\
Disturbance intensity & $2.06(0 \cdot 35)$ & 0.99 \\
Proportion of & $1.39(0 \cdot 38)$ & 0.72 \\
$\quad$ therophytes & & \\
Random site effects & & \\
ERC & $628 \cdot 1$ & \\
FAG & 547.7 & \\
LAU & 533.5 & \\
MAG & 529.6 & \\
MAR & 529.5 & \\
SAI & 595.3 & \\
SLP & 569.9 & \\
TDV & 524.5 & \\
THE & 585.2 &
\end{tabular}

ERC, LAU and SAI, upland sites with montane and subalpine climate; MAR and THE, continental climate; MAG and SLP, oceanic climate; FAG and TDV, Mediterranean climate. For further details on climate and management regimes in each site, see Table 1 and Fig. 1.

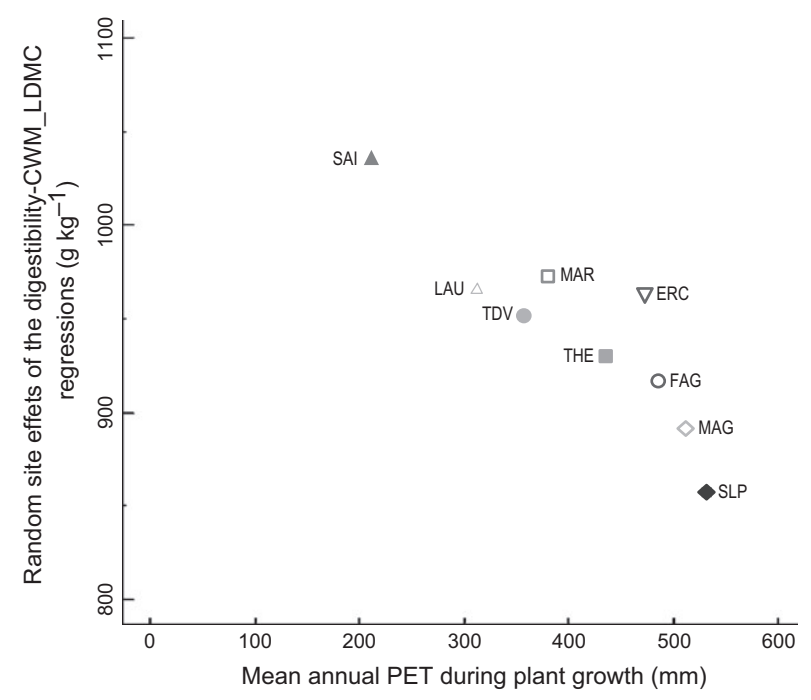

Fig. 4. Effect of potential evapotranspiration during plant growth on community digestibility in French permanent grasslands across nine sites. Values $\left(\mathrm{g} \mathrm{kg}^{-1}\right)$ are the intercepts of regressions between digestibility and community-weighted means of leaf dry matter content in each site represented in Fig. 3 (i.e. intercept + value of the random site effect of a mixed model, Table 3). ERC, LAU and SAI, upland sites with montane and subalpine climate; MAR and THE, continental climate; MAG and SLP, oceanic climate; FAG and TDV, Mediterranean climate. For further details on climate and management regimes in each site, see Table 1 and Fig. 1. 
$80 \%$ of therophytes) in FAG, MAG and TDV. It contributed to account for variance unexplained by LDMC, PET and disturbance intensity, but with a lower relative importance (Table 4). There was no detectable effect of either plant nutrition indices or phenological stage. Similarly, there was no significant interaction between any of the explanatory variables in this multiple regression analysis.

\section{Discussion}

\section{COMMUNITY DIGESTIBILITY AND TRAIT VARIATIONS ALONG GRADIENTS}

To our knowledge, the quantitative analysis of abiotic and biotic controls on community digestibility presented here and the use of the dominance hypothesis to scale up digestibility at community level are the first attempts involving multiple sites over a wide range of climates and management regimes.

When considered individually, management- and climate-related variables affected digestibility. The low community digestibility found under low disturbance intensity, and frequency was valid not only within some of the studied sites, as already shown in literature (e.g. Louault et al. 2005; Henkin et al. 2011), but also across the whole range of sites (Table 2). Drought intensity and duration had significant negative effects on digestibility, which is consistent with previous studies suggesting that species growing in moist areas tend to be more digestible than droughtresistant species adapted to arid areas and to high temperatures (Guérin 1999; Vázquez-de-Aldana et al. 2000; Craine et al. 2010). The results obtained here over a wider climatic gradient, with major differences in community composition between sites, differ from what could be observed within sites in response to interannual variations in water availability, showing that low soil moisture increases digestibility at the intraspecific level by reducing plant growth and stem development (Duru et al. 2000).

Across sites, NNI and PNI had negative and positive effects on digestibility, respectively, but these effects were not fully consistent within sites. This could result from multiple effects of fertilization according to phenological stage. At the plant level, fertilization increases digestibility early in the season (due to a reduction in the fraction of vascular tissues), but digestibility decreases more rapidly because fertilization enhances herbage growth (Duru 2008). These opposite effects of fertilization over time could not be disentangled in this study because plant traits and digestibility were measured only at vegetative peak. We did not account for seasonal variations in digestibility, which have already been described extensively in the literature (e.g. Pontes et al. 2007b; Duru et al. 2008). Instead, we focused here on other factors affecting digestibility patterns at a large geographical scale.

In agreement with our first hypothesis, all the community-weighted means of traits responded to grassland management regimes, but only partially to climate factors.
Among sites, community-weighted means of trait variations were mainly the result of species shifts, while at site level, CWM variations were caused by management regimes. High levels of disturbance, via biomass removal, and unstressed conditions (high plant nutrition indices, short drought period, low altitude) were associated with communities with low LDMC and high SLA, LNC and LPC values, consistent with previous studies (Lavorel \& Garnier 2002; Díaz et al. 2007; Cruz et al. 2010).

\section{EFFECTS OF TRAITS, CLIMATE AND MANAGEMENT FACTORS ON COMMUNITY DIGESTIBILITY}

In agreement with our second hypothesis, community digestibility was significantly related to several community-weighted means of traits. LDMC had the most consistent effects on digestibility, within and among sites, and was the only significant trait retained in the multiple regression analysis (the other traits having redundant effects with those of LDMC, and having less explanatory power). LDMC is indeed directly linked to cell walls' structural carbohydrate content (Garnier \& Laurent 1994), which is less digestible than the intracellular compartment (Duru et al. 2009).

At the species level, digestibility had already been correlated with SLA, LDMC (e.g. Al Haj Khaled et al. 2006) or plant height (Alexander et al. 2007), and in monospecific swards, Pontes et al. (2007a) showed that relationships between digestibility and LDMC or SLA were conserved among nitrogen fertilization and cutting frequency levels. It was, however, unknown whether these results applied at community level and in species-rich grasslands, where the dominance hypothesis was not formally assessed for digestibility. Our results show that this hypothesis actually holds at the community level and on a large range of sites. Over the nine sites studied, LDMC was the trait most frequently related to digestibility, while LNC was not kept in our final model (conversely to Lavorel \& Grigulis 2012). LDMC can therefore be used as a functional marker of digestibility.

The strength and novelty of our results lie in their generality: the negative effect of LDMC was found to be similar within individual sites spread over a wide environmental gradient (same LDMC digestibility slopes across sites), as shown in Fig. 3. As a response trait, the communityweighted mean of LDMC integrated several effects of environmental and land-use regimes on functional community structure, and thus indirectly on digestibility. However, the regression intercepts differed among sites (Fig. 3), and this among-site variability could be explained by PET (Fig. 4), where a $200 \mathrm{~mm}$ increase in PET would result in a $98 \mathrm{~g} \mathrm{~kg}^{-1}$ decline in digestibility. PET strongly depends on temperature: high temperatures accelerate tissue ageing, the deposition of lignin on cell wall materials and modify the structure of tillers. This may explain the observed reduction in digestibility, despite the fact that biomass samples were harvested at similar phenological stages. 
Most land-use variables, which controlled digestibility when considered alone, had no significant effect in the multiple regression model, suggesting that their effects on the functional composition of communities were accounted for by LDMC. Disturbance intensity was the only management variable to be retained in the final multiple regression, meaning that it also had a direct effect on digestibility. Indeed, defoliation maintained the herbage at a highly digestible vegetative stage, with a high leaf:stem ratio and a low proportion of structural tissues in each organ (Pontes et al. 2007b).

Greater relative abundance of therophytes resulted in increased community digestibility, an effect that was not accounted for by LDMC. This effect could originate from a lower degree of lignification of therophyte species (Xiong et al. 2006), improving the accessibility for digestive enzymes to their cell walls.

\section{MANAGEMENT APPLICATIONS AND PERSPECTIVES}

We had up to now only limited knowledge as to how the digestibility of species-rich native and permanent grasslands varies across large spatial scales. The originality of our study was thus to analyse the variations in digestibility of multispecies community, and to assess their dependency on climate conditions (i.e. uncontrolled environmental factors), and management practices.

Our findings indicate that community digestibility of permanent grasslands displays a wide range of variation. The disturbance regime (intensity and return interval of disturbance) and the local climate (potential evapotranspiration) drove digestibility with a similar magnitude. The effects of community composition on digestibility, and its response to abiotic factors, could be successfully captured by community-weighted means of LDMC, which can thus be considered as a powerful integrative functional marker of this ecosystem property.

Functional indicators such as LDMC may be used to manage the agro-ecosystems according to specific needs (i.e. herbage quantity and quality). In this paper, we focused on dry matter digestibility, which is the best estimator of forage nutritional value. Additional results (not shown) indicate that the total crude protein content analysed in our data set positively correlates with digestibility (Pearson correlation coefficient $=0.55, P<0.001)$, suggesting that these two components of nutritive value are not antagonistic. Much research is still required to identify more precisely the traits related to the other dimensions of forage quality (e.g. crude protein, secondary metabolites) and to identify which combination of traits (e.g. set of traits, functional diversity) provides the best trade-off between digestibility and the other components of forage quality.

To provide management recommendations for grassland managers, the next step will be to relate more precisely functional traits to effective practices across a diversity of livestock systems. Traits could then be used by farm advisers as proxies to link management practices and environmental conditions on the one hand and the resulting ecosystem services on the other hand. This has been done in a pilot study conducted on dairy farms in upland areas in France, where such a trait-based diagnostic tool is currently used to support farmers in the adaptation of their foraging practices to reach the new requirements for AOP dairy certification (Carrère et al. 2012).

Finally, our findings also show that drought and potential evapotranspiration were the two climate-related variables affecting most digestibility across spatial scales. This suggests that increasing drought in the context of climate change may depreciate forage quality, in addition to its potential effects on fodder production (Walter et al. 2012).

\section{Acknowledgements}

This work was supported by the INRA EcoGer project DivHerbe. We thank the staff of the La Fage INRA experimental station and of the INRA-Theix site of the SOERE-ACBB for support to carry out part of the fieldwork. The authors are grateful to C. Bernard-Brunet, O. Darsonville, G. Favier, O. Gimenez, C. Jouany, P. Lamarque, L. Lanore, J.L. Ollier, B. Pons, S. Rambal and B. Testi for their contribution to the data collection and analysis, as well as two reviewers for their helpful comments on the manuscript. A.G. was funded by a Montpellier SupAgro postdoctoral fellowship.

\section{References}

Al Haj Khaled, R., Duru, M., Decruyenaere, V., Jouany, C. \& Cruz, P. (2006) Using leaf traits to rank native grasses according to their nutritive value. Rangeland Ecology \& Management, 59, 648-654.

Alexander, G., Khan, A.A., Ravi, D., Bidinger, F.R., Hash, C.T. \& Blümmel, M. (2007) Morphological, chemical and in vitro stover quality traits to predict the livestock productivity potential of pearl millet stover. Journal of SAT Agricultural Research, 3, 4.

Andueza, D., Cruz, P., Farruggia, A., Baumont, R., Picard, F. \& Michalet-Doreau, B. (2010) Nutritive value of two meadows and relationships with some vegetation traits. Grass and Forage Science, 65, 325-334.

Ansquer, P., Duru, M., Theau, J.P. \& Cruz, P. (2009) Functional traits as indicators of fodder provision over a short time scale in species-rich grasslands. Annals of Botany, 103, 117-126.

Aufrère, J. \& Michaet-Doreau, B. (1983) In vivo digestibility and prediction of digestibility of some by-products. Feeding value of by-products and their use by beef cattle. EEC Seminar, 26-29 September, pp. 25-33. Melle-Gontrode, Belgium.

Barkaoui, K., Bernard-Verdier, M. \& Navas, M.-L. (2013) Questioning the reliability of the point intercept method for assessing community functional structure in low-productive and highly diverse Mediterranean grasslands. Folia Geobotanica, 48, 393-414.

Bruinenberg, M.H., Valk, H., Korevaar, H. \& Struik, P.C. (2002) Factors affecting digestibility of temperate forages from seminatural grasslands: a review. Grass and Forage Science, 57, 292-301.

Burnham, K.P. \& Anderson, D.R. (2002) Model Selection and Multimodel Inference: A Practical Information-Theoretic Approach, 2nd edn. Springer, New-York, USA.

Carrère, P., Seytre, L., Piquet, M., Landrieaux, J., Rivière, J., Chabalier, C. \& Orth, D. (2012) A multifunctional typology of grassland in AOP-certified dairy systems in the Massif Central combining an agronomic and ecological approach. Fourrages, 209, 9-21.

Choong, M.F., Lucas, P.W., Ong, J.S.Y., Pereira, B., Tan, H.T.W. \& Turner, I.M. (1992) Leaf fracture-toughness and sclerophylly: their correlations and ecological implications. New Phytologist, 121, 597-610.

Cornelissen, J.H.C., Lavorel, S., Garnier, E., Diaz, S., Buchmann, N., Gurvich, D.E. et al. (2003) A handbook of protocols for standardised and easy measurement of plant functional traits worldwide. Australian Journal of Botany, 51, 335-380.

Craine, J.M., Elmore, A.J., Olson, K.C. \& Tolleson, D. (2010) Climate change and cattle nutritional stress. Global Change Biology, 16, 2901-2911. 
Cruz, P., De Quadros, F.L.F., Theau, J.P., Frizzo, A., Jouany, C., Duru, M. \& Carvalho, P.C.F. (2010) Leaf traits as functional descriptors of the intensity of continuous grazing in native grasslands in the south of Brazil. Rangeland Ecology \& Management, 63, 350-358.

Díaz, S., Noy-Meir, I. \& Cabido, M. (2001) Can grazing response of herbaceous plants be predicted from simple vegetative traits? Journal of Applied Ecology, 38, 497-508.

Díaz, S., Lavorel, S., McIntyre, S., Falczuk, V., Casanoves, F., Milchunas, D.G. et al. (2007) Plant trait responses to grazing - a global synthesis. Global Change Biology, 13, 313-341.

Dumont, B., Rossignol, N., Loucougaray, G., Carrère, P., Chadœuf, J., Fleurance, G. et al. (2012) When does grazing generate stable vegetation patterns in temperate pastures? Agriculture, Ecosystems and Environment, 153, 50-56.

Duru, M. (2008) Improvement of time-driven models of lamina cocksfoot digestibility by a process-based model to take account of plant $\mathrm{N}$ nutrition and defoliation. Journal of Agronomy and Crop Science, 194, 401-412.

Duru, M., Cruz, P. \& Magda, D. (2004) Using plant traits to compare sward structure and composition of grass species across environmental gradients. Applied Vegetation Science, 7, 11-18.

Duru, M. \& Ducrocq, H. (2002) A model of lamina digestibility of orchardgrass as influenced by nitrogen and defoliation. Crop Science, $\mathbf{4 2}$, 214-223.

Duru, M., Delprat, V., Fabre, C. \& Feuillerac, E. (2000) Effect of nitrogen fertiliser supply and winter cutting on morphological composition and herbage digestibility of a Dactylis glomerata L. sward in spring. Journal of the Science of Food and Agriculture, 80, 33-42.

Duru, M., Cruz, P., Raouda, A.H.K., Ducourtieux, C. \& Theau, J.P. (2008) Relevance of plant functional types based on leaf dry matter content for assessing digestibility of native grass species and species-rich grassland communities in spring. Agronomy Journal, 100, $1622-1630$.

Duru, M., Khaled, R.A.H., Ducourtieux, C., Theau, J.P., de Quadros, F.L.F. \& Cruz, P. (2009) Do plant functional types based on leaf dry matter content allow characterizing native grass species and grasslands for herbage growth pattern? Plant Ecology, 201, 421-433.

Garcia, F., Carrère, P., Soussana, J.F. \& Baumont, R. (2003) How do severity and frequency of grazing affect sward characteristics and the choices of sheep during the grazing season? Grass and Forage Science, 58, $138-150$.

Garnier, É. \& Laurent, G. (1994) Leaf anatomy, specific mass and water-content in congeneric annual and perenial grass species. New Phytologist, 128, 725-736.

Garnier, É. \& Navas, M.-L. (2012) A trait-based approach to comparative functional plant ecology: concepts, methods and applications for agroecology. A review. Agronomy for Sustainable Development, 32, 365-399.

Garnier, É., Cortez, J., Billes, G., Navas, M.L., Roumet, C., Debussche, M. et al. (2004) Plant functional markers capture ecosystem properties during secondary succession. Ecology, 85, 2630-2637.

Grime, J.P. (1998) Benefits of plant diversity to ecosystems: immediate, filter and founder effects. Journal of Ecology, 86, 902-910.

Guérin, H. (1999) Valeur alimentaire des fourrages cultivés. Culture Fourragères Tropicales (eds G. Roberge \& B. Toutain), pp. 93-141. CIRAD, Montpellier, France.

Hargreaves, G.H. \& Allen, R.G. (2003) History and evaluation of Hargreaves evapotranspiration equation. Journal of Irrigation and Drainage Engineering-ASCE, 129, 53-63.

Henkin, Z., Ungar, E.D., Dvash, L., Perevolotsky, A., Yehuda, Y., Sternberg, M., Voet, H. \& Landau, S.Y. (2011) Effects of cattle grazing on herbage quality in a herbaceous Mediterranean rangeland. Grass and Forage Science, 66, 516-525.

Hirata, M. (1999) Modeling digestibility dynamics in leaf segments in a grass: a new approach to forage quality changes in a growing plant. Agricultural Systems, 60, 169-174.

Klimek, S., Kemmermann, A.R.G., Hofmann, M. \& Isselstein, J. (2007) Plant species richness and composition in managed grasslands: the relative importance of field management and environmental factors. Biological Conservation, 134, 559-570

Lavorel, S. \& Garnier, E. (2002) Predicting changes in community composition and ecosystem functioning from plant traits: revisiting the Holy Grail. Functional Ecology, 16, 545-556.

Lavorel, S. \& Grigulis, K. (2012) How fundamental plant functional trait relationships scale-up to trade-offs and synergies in ecosystem services. Journal of Ecology, 100, 128-140.
Lavorel, S., Grigulis, K., Lamarque, P., Colace, M.P., Garden, D., Girel, J., Pellet, G. \& Douzet, R. (2011) Using plant functional traits to understand the landscape distribution of multiple ecosystem services. Journal of Ecology, 99, 135-147.

Lemaire, G., Hodgson, J. \& Chabbi, A. (2011) Grassland Productivity and Ecosystem Services. CABI, Wallingford, Oxfordshire, UK.

Louault, F., Pillar, V.D., Aufrère, J., Garnier, E. \& Soussana, J.F. (2005) Plant traits and functional types in response to reduced disturbance in a semi-natural grassland. Journal of Vegetation Science, 16, 151-160.

Marriott, C.A., Fothergill, M., Jeangros, B., Scotton, M. \& Louault, F. (2004) Long-term impacts of extensification of grassland management on biodiversity and productivity in upland areas. A review. Agronomie, 24, 447-462.

Pavlů, V., Hejcman, M., Pavlů, L., Gaisler, J. \& Nežerková, P. (2006) Effect of continuous grazing on forage quality, quantity and animal performance. Agriculture Ecosystems \& Environment, 113, 349-355.

Pontes, L.D.S., Soussana, J.F., Louault, F., Andueza, D. \& Carrere, P. (2007a) Leaf traits affect the above-ground productivity and quality of pasture grasses. Functional Ecology, 21, 844-853.

Pontes, L.S., Carrere, P., Andueza, D., Louault, F. \& Soussana, J.F (2007b) Seasonal productivity and nutritive value of temperate grasses found in semi-natural pastures in Europe: responses to cutting frequency and N supply. Grass and Forage Science, 62, 485-496.

$\mathrm{R}$ Development Core Team (2008) R: a language and environment for statistical computing R Foundation for Statistical Computing, Vienna.

Rodrigues, A., Andueza, D., Picard, F., Cecato, U., Farruggia, A. \& Baumont, R. (2007) Valeur alimentaire et composition floristique des prairies permanentes: premiers résultats d'une étude conduite dans le Massif Central. Rencontres Autour Des Recherches Sur Les Ruminants, 14, 214-244.

Shenk, J.S. \& Westerhaus, M.O. (1994) The application of Near Infrared Reflectance Spectroscopy (NIRS) to forage analysis. Forage Quality, Evaluation and Utilization (eds M. Collins, D. R. Mertens \& L. E. Moser), pp. 406-449. American Society of Agronomy, Madison, Minnesota, USA.

Vázquez-de-Aldana, B.R., García-Ciudad, A., Pérez-Corona, M.E. \& García-Criado, B. (2000) Nutritional quality of semi-arid grassland in western Spain over a 10-year period: changes in chemical composition of grasses, legumes and forbs. Grass and Forage Science, 55, 209-220.

Violle, C., Navas, M.L., Vile, D., Kazakou, E., Fortunel, C., Hummel, I. \& Garnier, E. (2007) Let the concept of trait be functional!. Oikos, 116, 882-892.

Walter, J., Grant, K., Beierkuhnlein, C., Kreyling, J., Weber, M. \& Jentsch, A. (2012) Increased rainfall variability reduces biomass and forage quality of temperate grassland largely independent of mowing frequency. Agriculture Ecosystems \& Environment, 148, 1-10.

Xiong, Y.W., Fei, S.Z., Brummer, E.C., Moore, K.J., Barker, R.E., Jung, G.W., Curley, J. \& Warnke, S.E. (2006) QTL analyses of fiber components and crude protein in an annual $\mathrm{x}$ perennial ryegrass interspecific hybrid population. Molecular Breeding, 18, 327-340.

Received 28 October 2013; accepted 20 May 2014

Handling Editor: Jennifer Firn

\section{Supporting Information}

Additional Supporting Information may be found in the online version of this article.

Appendix S1. Calculation of environmental variables and details on statistical analyses.

Fig. S1. Distribution of the standard deviations of digestibility measurements at plot level, by site.

Table S1. Details on the factors of variation in the management regimes identified in each site.

Table S2. Means of plot relative abundance of the main species found over the nine sites

Table S3. Effects of climate variables and management regimes on community-weighted means of traits. 